\title{
SUPPLEMENTATION EFFECTS OF TANNIN AND SAPONIN EXTRACTS TO DIETS WITH DIFFERENT FORAGE TO CONCENTRATE RATIO ON In vitro RUMEN FERMENTATION AND METHANOGENESIS
}

\author{
Yogianto $^{1}$, A. Sudarman ${ }^{2}$, E. Wina ${ }^{3}$ and A. Jayanegara ${ }^{2}$ \\ ${ }^{1}$ Graduate School of Nutrition and Feed Science, Faculty of Animal Science, \\ Bogor Agricultural University, Jl. Agatis, Darmaga Campus, Bogor 16680 - Indonesia \\ ${ }^{2}$ Department of Nutrition and Feed Technology, Faculty of Animal Science, \\ Bogor Agricultural University, Jl. Agatis, Darmaga Campus, Bogor 16680 - Indonesia \\ ${ }^{3}$ Indonesian Research Center for Animal Production, Ciawi - Bogor 16002 - Indonesia \\ Corresponding E-mail:anu_jayanegara@yahoo.com
}

Received July 07, 2014; Accepted August 29, 2014

\begin{abstract}
ABSTRAK
Penelitian ini bertujuan untuk menginvestigasi pengaruh penambahan kombinasi ekstrak tanin dan saponin terhadap emisi gas metana dalam pakan dengan proporsi hijauan:konsentrat yang berbeda dalam fermentasi rumen secara in vitro. Rancangan percobaan menggunakan rancangan acak kelompok (RAK) pola factorial. Faktor pertama adalah proporsi hijauan:konsentrat dalam pakan (70:30 and 30:70) dan faktor kedua adalah penambahan ekstrak tanin dan saponin (kontrol, tanin, saponin, tanin+saponin) pada dosis $2 \mathrm{mg} / \mathrm{ml}$. Peubah yang diamati meliputi produksi gas, produksi gas metana, kecernaan bahan kering (KBK) dan bahan organik (KBO), dan konsentrasi amonia. Hasil menunjukkan bahwa penambahan tanin, saponin, dan kombinasinya secara umum menurunkan produksi gas dan metana pada kedua tipe pakan selama waktu inkubasi 24 dan 48 jam $(\mathrm{P}<0,05)$, namun kombinasi tanin dan saponin dibandingkan dengan penggunaan secara terpisah tidak menunjukkan perbedaan yang nyata. Penambahan kombinasi tanin dan saponin berpengaruh menurunkan KBK, KBO, dan ammonia secara nyata $(\mathrm{P}<0,05)$. Dapat disimpulkan bahwa penambahan ekstrak tanin, saponin dan kombinasi keduanya pada dosis $2 \mathrm{mg} / \mathrm{ml}$ dapat menurunkan emisi gas metana tetapi diikuti dengan menurunnya $\mathrm{KBK}$, KBO dan ammonia.
\end{abstract}

Kata kunci: tanin, saponin, hijauan, konsentrat, metana, in vitro

\begin{abstract}
This experiment was aimed to investigate the effect of combining tannin and saponin extracts on ruminal methane emission of diets with different proportion of forage to concentrate in the in vitro fermentation. The experiment was conducted in a factorial block design. The first factor was the proportion of forage:concentate in diets (70:30 and 30:70) and the second was addition of tannin and saponin extracts (control, tannins, saponins, tannins + saponins) in the dose of $2 \mathrm{mg} / \mathrm{ml}$. Variables observed were gas production kinetics, methane production, dry matter digestibility (DMD), organic matter digestibility (OMD) and ammonia concentration. Results revealed that addition of tannins, saponins and their combination generally lowered total gas and methane production during 24 and $48 \mathrm{~h}$ of incubation period in both types of diets $(\mathrm{P}<0.05)$, but combination of tannins and saponins compared with their separated forms did not show any significant differences. The addition of tannins, saponins and their combination reduced DMD, OMD and ammonia significantly $(\mathrm{P}<0.05)$. It can be concluded that the addition of tannin, saponin and their combination at a dose of $2 \mathrm{mg} / \mathrm{ml}$ could reduce methane emission but followed by a decline in the DMD, OMD and ammonia.
\end{abstract}

Keywords: tannin, saponin, forage, concentrate, methane, in vitro 


\section{INTRODUCTION}

Global warming is a major environmental problem faced by mankind, especially in the last century. Intergovernmental Panel on Climate Change (IPCC) in 2007 reported that the average temperature of earth's surface has increased by $0.74 \pm 0.18^{\circ} \mathrm{C}$ in the 20th century and such fact is the largest temperature rise within the last few thousand years. Furthermore, modeling scenarios developed by IPCC also suggest that the earth's surface temperature could increase by 2.4 to $6.4^{\circ} \mathrm{C}$ by the year of 2090 to 2099. If this is the case in the future, it will greatly impact on various aspects of human life. Main causes of global warming have been known to be associated with avery high rate of accumulation of greenhouse gases in theupper atmosphere such as carbon dioxide $\left(\mathrm{CO}_{2}\right)$, methane $\left(\mathrm{CH}_{4}\right)$, nitrous oxide $\left(\mathrm{N}_{2} \mathrm{O}\right)$ and chlorofluoro carbon $(\mathrm{CFC})$ as a result of the increasing intensity of various human activity (Thorpe, 2009). Methane is the second largest contributor to greenhouse gas $(16 \%$ of total) after $\mathrm{CO}_{2}$, but, its ability to retain heat (global warming potential) is 21 times higher than that of $\mathrm{CO}_{2}$ (Iqbal, 2008).

Livestock, especially ruminants like cattle, goats, and sheep contribute to accumulation of methane emmision in the atmosfer due to methanogenesis by archeametanogen in the rumen (Cottle et al., 2011). Such emission does not only affect the global warming, but it also represents energy loss from the animals, in which the lost can be between, 8 to $14 \%$ from total digestible energy. Nutritional strategies to mitigate methane emission based on natural substances are preferred over the synthetic ones (Jayanegara et al., 2009a). Accordingly, secondary plant metabolites such as tannins and saponins are potential to be used in mitigating methane emissions from ruminants. Tannins can reduce methane emissions through a reduction in methanogen population (Bhatta et al., 2009) whereas saponins work through a reduction in protozoa population (Hess et al., 2003) in which part of the methanogen is living symbiotically (Finlay et al., 1994). If these two compounds are used simultaneously, is could be expected to decrease in methane emission further.

Therefore, the purpose of this study was to investigate the effect of combining tannin and saponin extracts when added into two types of rations with different forage to concentrate ratio on ruminal methane emission, gas production, digestibility of dry matter and organic matter, and ammonia concentration through an in vitro assay.

\section{MATERIALS AND METHODS}

\section{Extraction of Tannins and Saponins}

Tannin extract was taken from the leaves of mahogany (Swieteniamahagoni) while the saponin extract was taken from the lerak fruit (Sapindusrarak) in which both of them were collected from Bogor area. Mahogany leaves and lerak fruits were oven-dried at $60^{\circ} \mathrm{C}$ to obtain approximately $90 \%$ dry matter and then, ground immediately to obtain powdered forms. Mahogany leaves powder extracted with a combination of $70 \%$ methanol:30\% water, while the lerak fruits powder was extracted with $100 \%$ methanol solvent by using an ultrasonic water bath for $30 \mathrm{~min}$ (Yuliana et al., 2014). Subsequently, the solid and liquid fractions were filtered using a Whatman paper. The liquid fraction was then evaporated in a rotary evaporator to evaporate the organic solvents, freeze dried and kept in air tight bags at freezer ($4^{\circ} \mathrm{C}$ ). These procedures produced dried tannin and saponin extracts.

\section{In Vitro Fermentation}

The substrate used in the in vitro test was consisted of two types of diet withdifferent forage to concentrate proportion, i.e.70:30 and 30:70, respectively. Forage used was elephant grass (Pennisetumpurpureum) with nutrient content (dry matter basis) of crude protein (CP): $8.96 \%$, neutral detergent fibre (NDF): $65.61 \%$, and acid detergent fibre (ADF): $44.72 \%$. The concentrate was a commercial concentrate of dairy cows with trademark Lactofeed produced from CV. Tani Mulya, Bogor, Indonesia, contained of $11.45 \%$ CP. The grass was dried in an oven at $50^{\circ} \mathrm{C}$ until themoisture content was around $10 \%$. The substrates were ground using a grinder to pass a 1 $\mathrm{mm}$ sieve size

The in vitro fermentation technique was according to the method of Theodorou (1990). A total of $100 \mathrm{mg}$ of substrate treatment was inserted into a $100 \mathrm{ml}$ bottle size and buffered rumen fluid as the incubation medium. The incubation medium was consisted bicarbonate buffer solution: (24.1\%), macro-mineral solution: (12.1\%), micro-mineral solution: $(0.00613 \%)$, resazurin: $(0.0612 \%)$, distilled water: $(36.2 \%)$, reducing solution: $(2.3 \%)$ and rumen fluid: $(25.3 \%)$. Rumen fluid was collected just before 
morning feeding from a rumen fistulated Friesian Holstein cow in Balai PenelitianTernak, Ciawi, Bogor; the cow was fed with elephant grass and commercial concentrate at a ratio of $60: 40$, respectively. The rumen fluid was filtered through a nylon cloth and, then inserted into a container and immediately brought to the laboratory. Incubation was carried out in a water bath maintained at $39-42^{\circ} \mathrm{C}$ for $48 \mathrm{~h}$. During the incubation, the bottles were shaked.

Factorial $(2 \times 4)$ randomized complete block was used in this study. Factor A: Different forage to concentrate ratio:

A1: $70 \%$ forage: $30 \%$ concentrate

A2: $30 \%$ forage: $70 \%$ concentrate

Factor B : Addition of tannin and or saponin extracts at (a dose of $2 \mathrm{mg} / \mathrm{ml}$ rumen fluid):

B1: Control

$\mathrm{B} 2: \mathrm{B} 1+2 \mathrm{mg} / \mathrm{ml}$ tannin extract

$\mathrm{B} 3: \mathrm{B} 1+2 \mathrm{mg} / \mathrm{ml}$ saponin extract

B4: B1 + $1 \mathrm{mg} / \mathrm{ml}$ tannin extract $+1 \mathrm{mg} / \mathrm{mL}$ saponin extract

\section{Variable Measurements}

Variables observed in this study were gas production kinetics, methane production, in vitro dry matter digestibility (DMD), in vitro organic matter digestibility (OMD) and ammonia concentration. Gas production was observed at 1 , $3,6,10,12,14,21,24,30,36$ and $48 \mathrm{~h}$ after incubation. Methane production was measured by using $\mathrm{CO}_{2}$ trapping method with $\mathrm{NaOH}$ at the interval when te residue was filtered and dried in an oven at $105{ }^{\circ} \mathrm{C}$ for $24 \mathrm{~h}$. Dry matter and organic matter residue were determined to calculate the DMD and OMD. Ammonia concentration was measured with the Conway micro-diffusion technique.

\section{Statistical Analysis}

Data obtained were analyzed by the factorial analysis of variance (ANOVA). When a particular variable showed significantly different at $\mathrm{P}<0.05$ in the ANOVA result, a post-hoc test namely Duncan's multiple range test was employed to compare among different treatment means. All statistical analyses were performed by using SPSS software version 17.

\section{RESULTS AND DISCUSSION}

\section{Total Gas and Methane Production}

Total gas production in vitro increased at higher incubation period but with a declining rate.
This is due to the decreasing quantity of fermentable substrates (Jayanegara et al., 2006). At high forage ration (HFR), addition of tannin and/or saponin extracts did not affect total gas production up to $6 \mathrm{~h}$ of in vitro incubation as compared to control; the change was begun later (Table 1). After $24 \mathrm{~h}$ incubation, the addition of tannins, saponins and their combination at $2 \mathrm{mg} / \mathrm{ml}$ in HFR significantly reduced the total gas production by $18.3,16.9$, and $11.2 \%$ from control, respectively $(\mathrm{P}<0.05)$. However, such additions to HCR did not decrease total gas production at $24 \mathrm{~h}$. Different pattern was observed at $48 \mathrm{~h}$ of incubation; addition of tannin and saponin extracts in combination increased total gas production especially in $\mathrm{HCR}$ as compared to control $(\mathrm{P}<0.05)$.

Total gas in the in vitro rumen fermentation is produced from the fermentation of substrates, primarily composed of $\mathrm{CO}_{2}$ and $\mathrm{CH}_{4}$ (Getachew et al., 1998). The reduction of gas production at $24 \mathrm{~h}$ fermentation due to addition of tannin extract was in agreement with Jayanegara et al. (2009a) although the level tested was different. While the decline in gas production due to the addition of saponin extract was also observed by Makkar et al. (1995). Mechanism of tannins in reducing gas production is through their ability to interact withfeed components mainly protein and fiber which have a major contribution in generating gas (Makkar, 2003; Makkar et al., 2007), whereas the mechanism of saponins is more ability to inhibit the activity of enzymes that degrade the fiber components (Hristov et al., 2003). Interestingly, when tannins and saponins were combined, the addition did not decrease gas production especially at longer incubation period. Apparently they interacts each other and alleviate the negative impact on the in vitro rumen fermentation activity. In relation to starting from $3 \mathrm{~h}$ of incubation until the end $(48 \mathrm{~h})$, HCR produced lower methane concentration than that of $\operatorname{HFR}(\mathrm{P}<0.05$; Table 2$)$. Additions of tannins, saponins and the combination of tannins+saponins generally decreased methane concentration as compared to control both in HFR and HCR $(\mathrm{P}<0.05)$. The response was consistent until $48 \mathrm{~h}$ of incubation. No significant interaction was found between different forage to concentrate diet and tannin/saponin additions. Simultaneous addition of tannins+saponins lowered methane concentration than their individual addition especially during early incubation period and in HCR. 
Table 1.Gas Production Kinetics (in ml) of High Forage Ration (HFR) and High Concentrate Ration (HCR) on Addition of tannin and Saponin Extracts

\begin{tabular}{|c|c|c|c|c|c|c|c|c|c|c|c|}
\hline \multirow{2}{*}{$\begin{array}{l}\text { Time } \\
\text { (h) }\end{array}$} & \multicolumn{4}{|c|}{ HFR $(70 \% \mathrm{~F}: 30 \% \mathrm{C})$} & \multicolumn{4}{|c|}{ HCR (30\%F:70\%C) } & \multicolumn{3}{|c|}{ Significancy } \\
\hline & Ctl & $\mathrm{T}$ & $\mathrm{S}$ & $\mathrm{T}+\mathrm{S}$ & $\mathrm{Ctl}$ & $\mathrm{T}$ & $\mathrm{S}$ & $\mathrm{T}+\mathrm{S}$ & $\mathrm{FC}$ & TS & INT \\
\hline 1 & $15.7^{\mathrm{a}}$ & $16.2^{\mathrm{ab}}$ & $16.2^{\mathrm{ab}}$ & $20.8^{\mathrm{abc}}$ & $17.8^{\mathrm{ab}}$ & $19.8^{\mathrm{ab}}$ & $20.9^{b c}$ & $24.8^{c}$ & $* *$ & $* *$ & ns \\
\hline 3 & $30.6^{\mathrm{ab}}$ & $28.6^{\mathrm{a}}$ & $31.7^{\mathrm{ab}}$ & $33.8^{\mathrm{ab}}$ & $34.6^{\mathrm{ab}}$ & $35.3^{\mathrm{bc}}$ & $40.5^{\mathrm{cd}}$ & $41.3^{\mathrm{d}}$ & $* *$ & $* *$ & ns \\
\hline 6 & $46.3^{\mathrm{a}}$ & $42.7^{\mathrm{a}}$ & $47.8^{\mathrm{ab}}$ & $51.4^{\mathrm{abc}}$ & $59.7^{\text {cde }}$ & $56.8^{\mathrm{bcd}}$ & $62.8^{\mathrm{de}}$ & $68.9^{\mathrm{e}}$ & $* *$ & $*$ & ns \\
\hline 10 & $77.9^{\mathrm{bc}}$ & $58.2^{\mathrm{a}}$ & $69^{\mathrm{ab}}$ & $72.1^{\mathrm{b}}$ & $99.1^{\mathrm{de}}$ & $87.7^{\mathrm{cd}}$ & $96.7^{\mathrm{de}}$ & $104^{\mathrm{e}}$ & $* *$ & $*$ & ns \\
\hline 12 & $94.9^{\mathrm{bc}}$ & $67.7^{\mathrm{a}}$ & $81.5^{\mathrm{b}}$ & $83.2^{\mathrm{b}}$ & $116.9^{\mathrm{de}}$ & $104.7^{\mathrm{cd}}$ & $119.9^{\mathrm{e}}$ & $123.5^{\mathrm{e}}$ & $* *$ & $* *$ & $\mathrm{~ns}$ \\
\hline 14 & $109.6^{\mathrm{c}}$ & $77.1^{\mathrm{a}}$ & $91.6^{\mathrm{b}}$ & $93.1^{\mathrm{b}}$ & $131.9^{\mathrm{de}}$ & $119.4^{\mathrm{cd}}$ & $136.6^{\mathrm{e}}$ & $139.5^{\mathrm{e}}$ & $* *$ & $* *$ & $\mathrm{~ns}$ \\
\hline 21 & $140.2^{b}$ & $110.4^{\mathrm{a}}$ & $113.6^{\mathrm{a}}$ & $121^{\mathrm{a}}$ & $158.9^{\mathrm{c}}$ & $154.1^{\mathrm{c}}$ & $160.5^{\mathrm{c}}$ & $164.3^{\mathrm{c}}$ & $* *$ & $* *$ & $*$ \\
\hline 24 & $151^{\mathrm{b}}$ & $123.4^{\mathrm{a}}$ & $125.5^{\mathrm{a}}$ & $134.1^{\mathrm{a}}$ & $167.5^{\mathrm{c}}$ & $165.8^{\mathrm{c}}$ & $169.3^{c}$ & $174^{\mathrm{c}}$ & $* *$ & $*$ & $*$ \\
\hline 30 & $164.9^{\mathrm{b}}$ & $147.7^{\mathrm{a}}$ & $141.7^{\mathrm{a}}$ & $152.2^{\mathrm{ab}}$ & $178^{\mathrm{c}}$ & $180.4^{\mathrm{c}}$ & $180.9^{c}$ & $185.8^{\mathrm{c}}$ & $* *$ & ns & $*$ \\
\hline 36 & $173.2^{\mathrm{bc}}$ & $162.1^{\mathrm{ab}}$ & $156.4^{\mathrm{a}}$ & $168.9^{\mathrm{a}}$ & $183.7^{\mathrm{cd}}$ & $188.6^{\mathrm{d}}$ & $190.3^{\mathrm{d}}$ & $195.5^{\mathrm{d}}$ & $* *$ & ns & ns \\
\hline 48 & $184.8^{\mathrm{bc}}$ & $174.3^{\mathrm{ab}}$ & $169.5^{\mathrm{a}}$ & $187.4^{\mathrm{c}}$ & $190.1^{\mathrm{cd}}$ & $199.2^{\mathrm{d}}$ & $203.2^{\mathrm{e}}$ & $207.5^{\mathrm{e}}$ & $* *$ & $*$ & $* *$ \\
\hline
\end{tabular}

Different superscripts within the same row are significantly different at $\mathrm{P}<0.05$

$\mathrm{F}=$ forage; $\mathrm{C}=$ concentrate; $\mathrm{Ctl}=$ control; $\mathrm{T}=$ tannin; $\mathrm{S}=$ saponin; $\mathrm{T}+\mathrm{S}=\operatorname{tannin}+$ saponin; $\mathrm{FC}=$ factor forage to concentrate ratio; TS $=$ factor addition of tannin and saponin; INT $=$ interaction between $\mathrm{FC}$ and $\mathrm{TS} ; * *=$ highly significant $(\mathrm{P}<0.01) ; *=$ Significant $(\mathrm{P}<0.05) ; \mathrm{ns}=$ non-significant

Table 2.Methane Production (in \% Total Gas) of High Forage Ration (HFR) and High Concentrate Ration (HCR) on Addition of Tannin and Saponin Extracts

\begin{tabular}{|c|c|c|c|c|c|c|c|c|c|c|c|}
\hline \multirow{2}{*}{$\begin{array}{l}\text { Time } \\
\text { (h) }\end{array}$} & \multicolumn{4}{|c|}{ HFR (70\%F:30\%C) } & \multicolumn{4}{|c|}{$\mathrm{HCR}(30 \% \mathrm{~F}: 70 \% \mathrm{C})$} & \multicolumn{3}{|c|}{ Significancy } \\
\hline & $\mathrm{Ctl}$ & $\mathrm{T}$ & S & $\mathrm{T}+\mathrm{S}$ & $\mathrm{Ctl}$ & $\mathrm{T}$ & $\mathrm{S}$ & $\mathrm{T}+\mathrm{S}$ & FC & TS & INT \\
\hline 1 & $34.14^{\mathrm{c}}$ & $26.002^{\mathrm{ab}}$ & $27.55^{\mathrm{ab}}$ & $23.099^{\mathrm{ab}}$ & $29.03^{b c}$ & $26.21^{\mathrm{ab}}$ & $25.02^{\mathrm{ab}}$ & 2206 & ns & $* *$ & ns \\
\hline 3 & $36.20^{\mathrm{d}}$ & $26.83^{b c}$ & $25.34^{\mathrm{bc}}$ & $23.094^{\mathrm{ab}}$ & $28.33^{\mathrm{c}}$ & $27.58^{\mathrm{c}}$ & $22.95^{\mathrm{ab}}$ & $20.91^{\mathrm{a}}$ & $*$ & $* *$ & ns \\
\hline 6 & $34.48^{\mathrm{d}}$ & $28.65^{\mathrm{c}}$ & $26.61^{\mathrm{abc}}$ & $24.38^{\mathrm{ab}}$ & $28.11^{\mathrm{bc}}$ & $27.42^{\mathrm{bc}}$ & $24.11^{\mathrm{ab}}$ & $22.85^{\mathrm{a}}$ & $* *$ & $* *$ & ns \\
\hline 10 & $33.81^{\mathrm{d}}$ & $28.82^{\mathrm{c}}$ & $28.11^{b c}$ & $24.51^{\mathrm{ab}}$ & $27.90^{\mathrm{bc}}$ & $26.45^{\mathrm{bc}}$ & $24.45^{\mathrm{ab}}$ & $22.19^{\mathrm{a}}$ & $* *$ & ** & ns \\
\hline 12 & $32.87^{\mathrm{d}}$ & $27.77^{\mathrm{c}}$ & $27.30^{\mathrm{bc}}$ & $24.73^{a b c}$ & $27.35^{\text {bc }}$ & $25.59^{\mathrm{abc}}$ & $24.12^{\mathrm{ab}}$ & $22.27^{\mathrm{a}}$ & $* *$ & $* *$ & ns \\
\hline 14 & $32.08^{\mathrm{d}}$ & $27.67^{\mathrm{c}}$ & $26.63^{b c}$ & $24.68^{\mathrm{ab}}$ & $26.53^{b c}$ & $25.29^{\mathrm{bc}}$ & $23.88^{\mathrm{ab}}$ & $22.14^{\mathrm{a}}$ & $* *$ & $* *$ & ns \\
\hline 21 & $31.21^{\mathrm{d}}$ & $26.85^{\mathrm{bc}}$ & $26.50^{\mathrm{bc}}$ & $24.68^{\mathrm{abc}}$ & $26.99^{c}$ & $22.66^{\mathrm{abc}}$ & $24.03^{\mathrm{ab}}$ & $22.66^{\mathrm{a}}$ & $* *$ & $* *$ & ns \\
\hline 24 & $31.23^{\mathrm{d}}$ & $26.60^{\mathrm{c}}$ & $26.22^{\mathrm{bc}}$ & $24.78^{\mathrm{abc}}$ & $27.07^{\mathrm{c}}$ & $25.12^{\mathrm{abc}}$ & $23.91^{\mathrm{ab}}$ & $22.75^{\mathrm{a}}$ & $* *$ & $* *$ & $\mathrm{~ns}$ \\
\hline 30 & $30.99^{d}$ & $24.70^{\mathrm{abc}}$ & $26.30^{\mathrm{bc}}$ & $24.56^{\mathrm{bc}}$ & $27.12^{\mathrm{c}}$ & $25.14^{\mathrm{abc}}$ & $24.05^{\mathrm{ab}}$ & $22.47^{\mathrm{a}}$ & $* *$ & $* *$ & ns \\
\hline 36 & $30.95^{\mathrm{d}}$ & $24.32^{\mathrm{ab}}$ & $25.96^{\mathrm{bc}}$ & $24.21^{b c}$ & $27.22^{\mathrm{c}}$ & $25.08^{\mathrm{abc}}$ & $24.22^{\mathrm{ab}}$ & $22.54^{\mathrm{a}}$ & $*$ & $* *$ & ns \\
\hline 48 & $31.13^{\mathrm{c}}$ & $23.90^{\mathrm{a}}$ & $25.37^{\mathrm{ab}}$ & $24.46^{\mathrm{a}}$ & $27.31^{b}$ & $24.96^{\mathrm{ab}}$ & $24.24^{\mathrm{a}}$ & $22.68^{\mathrm{a}}$ & $*$ & $* *$ & ns \\
\hline
\end{tabular}

Explanation of Ctl, T, S, FC, TS, INT, * and **: see Table 1 
Effect of tannins in reducing methane emission on high forage ration was in line with that reported by Jayanegara et al. (2010); addition of purified tannins from chestnut and Sumach at 1 $\mathrm{mg} / \mathrm{ml}$ into hay:concentrate (70:30) diet decreased methane concentration by 6.5 and $7.2 \%$, respectively. With regard to saponins, in contrast to the present study, saponins from lerak fruits did not decrease rumen methanogens which can be correlated with the methane emissions. Such difference may occur because of the differences in the dose of saponin extracts, duration of incubation, and the incubation medium. Other reports have shown the methane mitigation effect of saponins from various sources, such as from Camellia sinensis (Guo et al., 2008) and Knautiaarvensis (Goel et al., 2008). The ability of tannins and saponins to reduce ruminal methane emissions has different mechanisms. Tannins, including hydrolysable and condensed tannins reduce methane through a direct inhibition on archea metanogen population in the rumen (Bhatta et al., 2009). On the other hand, saponins decrease methane through a reduction in ruminal protozoal population (Hess et al., 2003) in which part of the methanogens are symbiotically living together with the fauna and contribute up to $37 \%$ of the total methane emissions from the rumen (Finlay et al.,1994).

\section{Feed Digestibility and Fermentation}

Data on feeddry matter digestibility (DMD) and organic matter digestibility (OMD) are presented in Figure 1 and Figure 2, respectively. The addition of tannins, saponins and their combination at $2 \mathrm{mg} / \mathrm{ml}$ during the $48 \mathrm{~h}$ incubation period significantly decreased DMD and OMD $(\mathrm{P}<0.05)$. TheDMD decrease on the addition of tannins, saponins and the combination in HFR $20.7 \%, 20.5 \%$ and $24.7 \%$, respectively, in HCR were $19.0 \%, \quad 12.2 \%$ and, $13.3 \%$, respectively. Similarly, OMD decrease due to addition of tannins, saponins and tannins+saponins were $35.0 \%, 27.2 \%$ and $30.7 \%$, respectively in HFR and $19.9 \%, 16.2 \%$ and $16.1 \%$ in HCR. The decline of ruminal digestibility due to addition of tannins and/or saponins has also been reported by some other authors (Makkar et al., 1995; Wina et al., 2005; Jayanegara et al., 2009b). The mechanisms of tannins and saponins in reducing ruminal digestibility of dry matter and organic matter are similar as in the reduction of gas production; tannins inhibit feed degradation process through their interactions with protein and fiber components (Makkar, 2003; Makkar et al., 2007) while saponins inhibit the activity of enzymes that degrade fiber components (Hristov et al., 2003).

Addition of saponins and the combination resulted in the decrease of rumen ammonia concentration both in HFR and HCR $(\mathrm{P}<0.05$; Figure 3). No difference was observed between HFR and HCR with regard to ammonia concentration. Combination of tannins+saponins decreased ammonia further than those of their individuals $(\mathrm{P}<0.05)$. This may indicate the

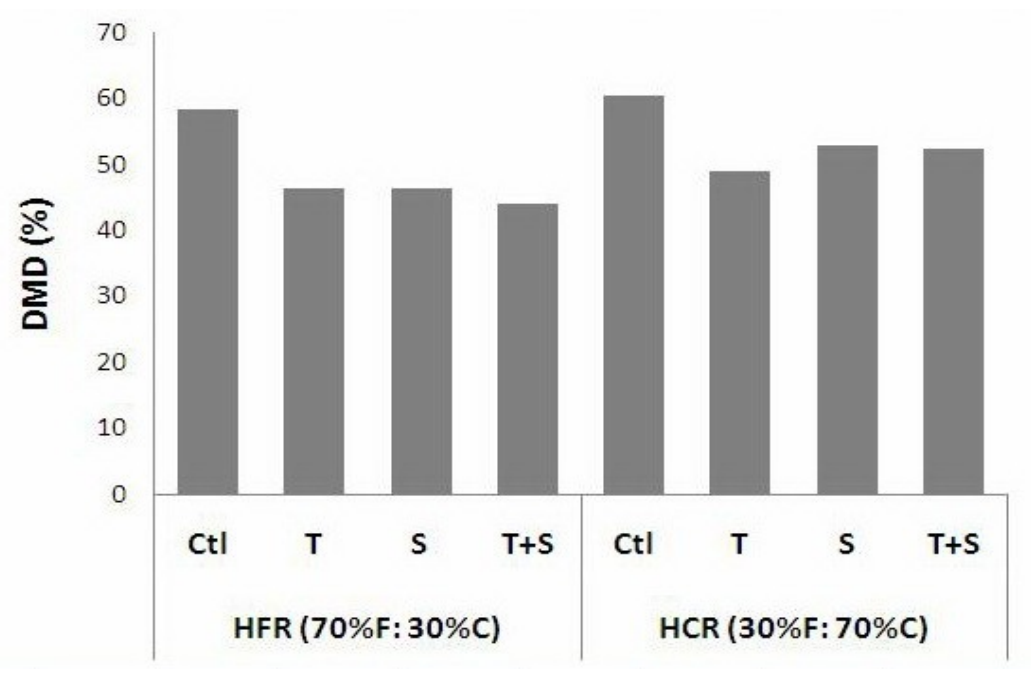

Figure 1. Dry Matter Digestibility (DMD) of High Forage Ration (HFR) and High Concentrate Ration (HCR) on Addition of Tannin and Saponin Extracts. Ctl = control; $\mathrm{T}=\operatorname{tannin} ; \mathrm{S}=$ saponin; $\mathrm{T}+\mathrm{S}=$ tannin + saponin; $\mathrm{HFR}=$ high forage ration; $\mathrm{HCR}=$ high concentrate ration; $\mathrm{F}=$ forage; $\mathrm{C}=$ concentrate. 


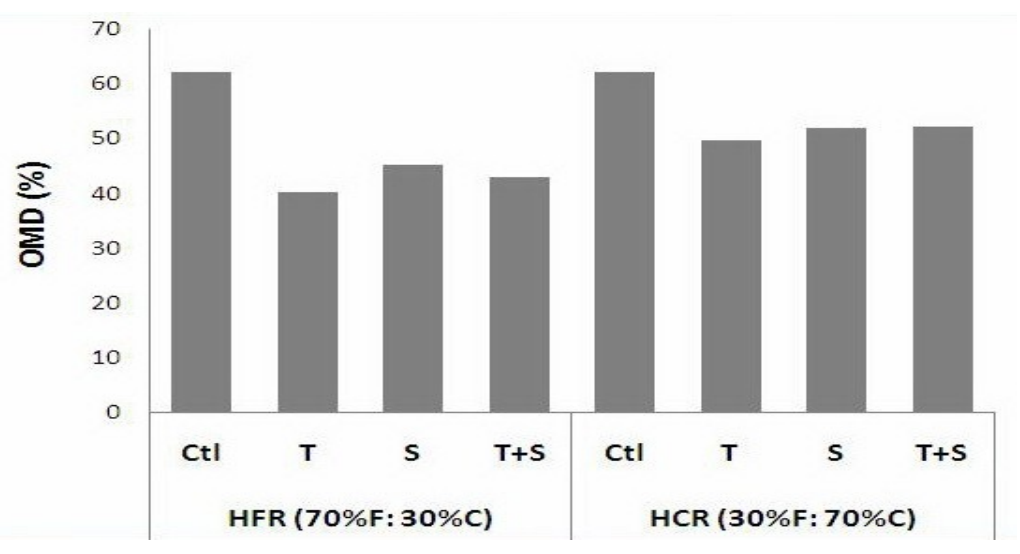

Figure 2. Organic Matter Digestibility (OMD) of High Forage Ration (HFR) and High Concentrate Ration (HCR) on Addition of Tannin and Saponin Extracts. Ctl : control; $\mathrm{T}:$ tannin; S : saponin; $\mathrm{T}+\mathrm{S}$ : tannin + saponin; HFR : high forage ration; HCR : high concentrate ration; F : forage; $\mathrm{C}:$ concentrate.

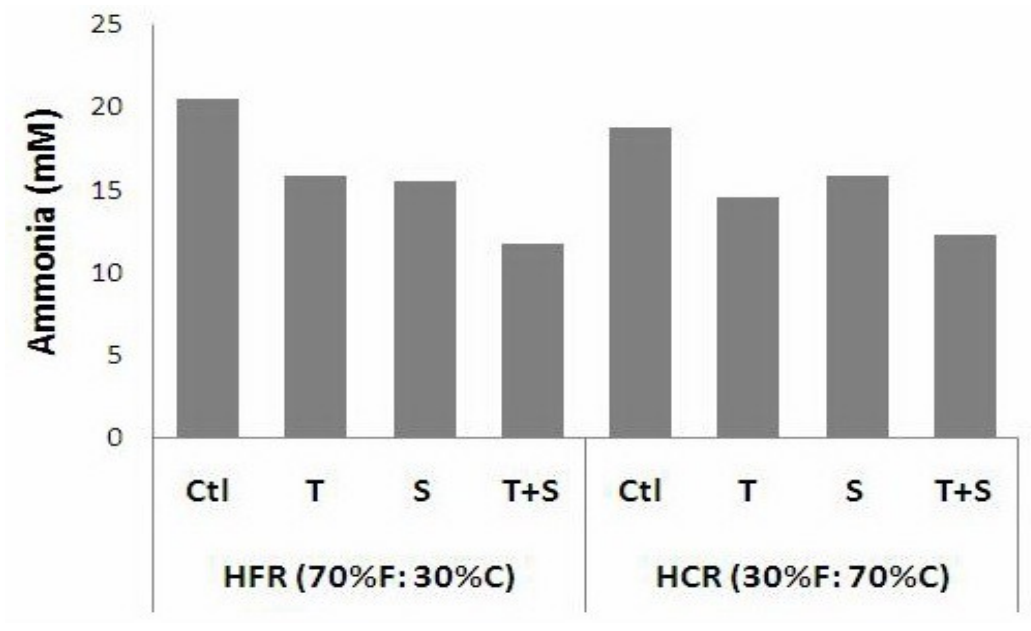

Figure 3. Ammonia Concentration of High Forage Ration (HFR) and High Concentrate Ration (HCR) on Addition of Tannin and Saponin Extracts. Ctl : control; $\mathrm{T}:$ tannin; S : saponin; T+S : tannin + saponin; HFR : high forage ration; HCR : high concentrate ration; $\mathrm{F}$ : forage; $\mathrm{C}:$ concentrate.

presence of associative effect between tannins and saponins in decreasing rumen ammonia concentration. A number of studies have reported that tannins and saponins reduced ammonia concentration in the rumen, both in vitro and in vivo (Makkar et al., 1998; Wina et al., 2005).

Concentration of ammonia in the rumen is derived from the lysis of microbes and degradation of feed protein. Most of ammonia is absorbed through the rumen wall and the rest is used directly by rumen microbes to meet the needs of nitrogen; about $50-80 \%$ requirements for microbial nitrogen is derived from ammonia (Leng, 1984). Tannins decrease ammonia concentrations of ammonia by binding with feed protein and, hence, prevent its degradation by proteolytic microbes (Tanner et al., 1994). The decrease in ammonia due to the addition of saponins occurred by an indirect mechanism through a reduced protozoal population (VanSoest, 1994). When both tannins and saponins were added simultaneously, apparently both mechanisms occur and lead a synergistic effect for further reduction of rumen ammonia 
concentration.

\section{CONCLUSION}

Addition of tannins, saponins and their combination were able to reduce ruminal methane emissions in vitro when added both in high fiber and high concentrate rations at $2 \mathrm{mg} / \mathrm{ml}$. Although the additions also decreased DMD, OMD and ammonia concentration in the rumen, it does not always mean that a negative effect on animal performance will occur. It has to be noted that the depression of digestibility is taken place in the rumen, not in the total digestive tract. Further in vivo study is therefore needed to confirm the present in vitro results and to investigate their effects on animal performance.

\section{REFERENCES}

Beauchemin, K.A., M. Kreuzer, F. O'Mara and T.A McAllister. 2008. Nutritional management for enteric methane abatement: a review. Aust. J. Exp. Agric. 48:21-27

Bhatta, R., Y. Uyeno, K. Tajima, A. Takenaka, Y. Yabumoto, I. Nonaka, O. Enishi and M. Kurihara. 2009. Difference in the nature of tannins on in vitro ruminal methane and volatile fatty acid production and on methanogenicarchaea and protozoal populations. J. Dairy Sci. 92:5512-5522.

Cottle, D.J., J.V. Nolan and S.G. Wiedemann. 2011. Ruminant enteric methane mitigation: a review. Anim. Prod. Sci. 51:491-514

Finlay, D.J., G. Esteban, K.J. Clarke, A.G. Williams, T.M, Embley and R.P. Hirt. 1994. Some rumen ciliates have endosymbioticmethanogenesis. FEMS Microbiol.Lett. 117:157-162.

Getachew, G., M. Blummel, H.P.S. Makkar and K. Becker. 1998. In vitro gas measuring techniques for assessment of nutritional quality of feeds: a review. Anim. Feed Sci. Technol. 72:261-281

Goel, G., H.P.S Makkar and K. Becker. 2008. Effects of sesbaniasesban and carduuspycnocephalus leaves and fenugreek (Trigonellafoenum-graecum L.) seeds and their extracts on partitioning of nutrients from roughage- and concentratebased feeds to methane. Anim. Feed Sci. Technol. 147:72-89

Guo, Y.Q., J.X. Liu, Y. Lu, W.Y. Zhu, S.E. Denman and C.S. McSweeney. 2008. Effect of tea saponin on methanogenesis, microbial community structure and expression of mcrA gene in cultures of rumen microorganisms. Lett. Appl. Microbiol. 47: 421-426

Hess, H.D., M. Kreuzer, T.E. Diaz, C.E. Lascano, J.E. Carulla, C.R. Soliva and A. Machmuller. 2003. Saponin rich tropical fruits affect fermentation and methanogenesis in faunated and defaunated rumen fluid. Anim. Feed Sci. Technol. 109: 79-94

Hristov, A.N., M. Ivan, L. Neill and T.A. McAllister. 2003. Evaluation of several potential bioactive agents for reducing protozoal activity in vitro. Anim. Feed Sci. Technol. 105: 163-184

Iqbal, M.F., Y.F. Cheng, W.Y. Zhu and B. Zeshan. 2008. Mitigation of ruminant methane production: currect strategies, constraints and future options. World J. Microbiol.Biotechnol. 24: 2747-2755

Jayanegera, A. A.S. Tjakradidjaja and T. Sutardi. 2006. Fermentabilitas dan kecernaan in vitro ransum limbah agroindustri yang disuplementasi kromium organik dan anorganik. Med. Pet. 29:54-62

Jayanegara, A., H.P.S. Makkar and K. Becker. 2009a. Emisimetanadanfermentasi rumen in vitro ransum hay yang mengandung tannin murnipadakonsentrasirendah. Med. Pet. 32: 184-194

Jayanegara, A. A. Sofyan, H.P.S. Makkar and K. Bekker. 2009b. Kinetika produksi gas, kecernaan bahan organik dan produksi gas metana in vitro pada hay dan jerami yang disuplementasi hijauan mengandung tanin. Med. Pet. 32:120-129

Jayanegara, A., G. Goel, H.P.S. Makkar and K. Becker. 2010. Reduction in methane emissions from ruminants by plant secondary metabolites: effects of polyphenols and saponins. In: Odongo, N.E., M. Garcia and G.J. Viljoen (Eds.). Sustainable Improvement of Animal Production and Health.Food and Agriculture Organization, Rome, Italy, pp. 151-157

Leng, R.A. and J.V. Nolan. 1984. Nitrogen metabolism in the rumen. J. Dairy Sci. 67: 1072- 1089.

Makkar, H.P.S. 2003. Effects and fate of tannins in ruminant animals, adaptation to tannins, and strategies to overcome detrimental 
effects of feeding tannin-rich feeds. Small Rum. Res. 49: 241-256.

Makkar, H.P.S., M. Blummel and K. Becker. 1995. In vitro effects of and interactions between tannins and saponins and fate of tannins in the rumen. J. Sci. Food Agric. 69: 481-493

Makkar, H.P.S., G. Francis and K. Becker. 2007. Bioactivity of phytochemicals in some lesser known plants and their effects and potential applications in livestock and aquaculture production systems. Animal 1: 1371-1391

Makkar, H.P.S., S. Sen, M. Blummel and K. Becker. 1998. Effect of fractions containing saponins from Yucca schidigera, Quillajasaponaria and ccaciaauriculoformis on rumen fermentation. J. Agric. Food Chem. 46:4324-4328

Tanner, G.J., A.E. Moore and P.J. Larkin. 1994. Proanthocyanidins inhibit hydrolysis of leaf proteins by rumen microflora in vitro. J. Nutr. 74: 947-958

Theodorou M.K. and A.E. Brook. 1990. Evaluation of a New Laboratory Procedure for Estimating the Fermentation Kinetic of Tropical Feeds. Annual Report AFRC
Institute, Hurley, Maidenhead, UK.

Thorpe, A. 2009. Enteric fermentation and ruminant eructation: the role (and control?) of methane in the climate change debate. Climate Change 93:407-431

Van Soest, P.J. 1994. Nutritional Ecology of the Ruminant. Cornell University Press: United States.

Wina, E., S. Muetzel and K. Becker. 2005. The dynamics of majorfibrolytic microbes and enzyme activity in the rumen in response to short and long term feeding of Sapindusraraksaponins. J. Appl. Microbiol. 100:114-122

Wina, E., S. Muetzel, E. Hoffman, H.P.S. Makkar and K. Becker. 2005. Saponins containing methanol extract of Sapindusrarak affect microbial fermentation, microbial activity and microbial community structure in vitro. Anim. Feed Sci. Technol. 121:159-174

Yuliana, P., E.B. Laconi, E. Wina and A. Jayanegara. 2014. Extractions of tannins and saponins from plant sources and their effects on methanogenesis and rumen fermentation in vitro. J. Indonesian Trop. Anim. Agric. 39(2):90-96 